\title{
Whey protein-polysaccharide conjugates obtained via dry heat treatment to improve the heat stability of whey protein stabilized emulsions
}

\author{
Setiowati, Arima Diah; Wijaya, Wahyu; Van der Meeren, Paul
}

Published in:

Trends in Food Science and Technology

Link to article, DOI:

10.1016/j.tifs.2020.02.011

Publication date:

2020

Document Version

Peer reviewed version

Link back to DTU Orbit

Citation (APA):

Setiowati, A. D., Wijaya, W., \& Van der Meeren, P. (2020). Whey protein-polysaccharide conjugates obtained via dry heat treatment to improve the heat stability of whey protein stabilized emulsions. Trends in Food Science and Technology, 98, 150-161. https://doi.org/10.1016/j.tifs.2020.02.011

\section{General rights}

Copyright and moral rights for the publications made accessible in the public portal are retained by the authors and/or other copyright owners and it is a condition of accessing publications that users recognise and abide by the legal requirements associated with these rights.

- Users may download and print one copy of any publication from the public portal for the purpose of private study or research.

- You may not further distribute the material or use it for any profit-making activity or commercial gain

- You may freely distribute the URL identifying the publication in the public portal 


\section{Journal Pre-proof}

Whey protein-polysaccharide conjugates obtained via dry heat treatment to improve the heat stability of whey protein stabilized emulsions

Arima Diah Setiowati, Wahyu Wijaya, Paul Van der Meeren

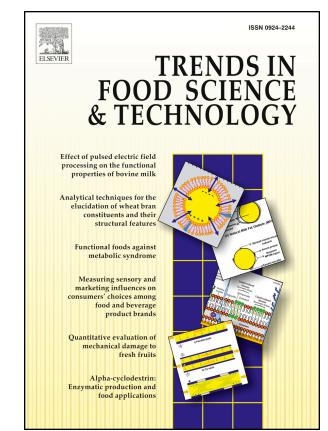

PII:

S0924-2244(19)30653-3

DOI:

https://doi.org/10.1016/j.tifs.2020.02.011

Reference: TIFS 2746

To appear in: Trends in Food Science \& Technology

Received Date: 8 August 2019

Revised Date: 28 January 2020

Accepted Date: 15 February 2020

Please cite this article as: Setiowati, A.D., Wijaya, W., Van der Meeren, P., Whey protein-polysaccharide conjugates obtained via dry heat treatment to improve the heat stability of whey protein stabilized emulsions, Trends in Food Science \& Technology (2020), doi: https://doi.org/10.1016/j.tifs.2020.02.011.

This is a PDF file of an article that has undergone enhancements after acceptance, such as the addition of a cover page and metadata, and formatting for readability, but it is not yet the definitive version of record. This version will undergo additional copyediting, typesetting and review before it is published in its final form, but we are providing this version to give early visibility of the article. Please note that, during the production process, errors may be discovered which could affect the content, and all legal disclaimers that apply to the journal pertain.

(C) 2020 Published by Elsevier Ltd. 
Abstract

\section{Background}

As the demand for "clean label emulsions" and natural emulsifiers is increasing, whey proteins have a big potency to be used as an emulsifier in food emulsions. However, in order to enable their application, whey proteins should withstand high temperature processing. Hence, the limited heat stability of whey proteins is a major drawback: they are highly heat labile and thus prone to heat induced protein denaturation and aggregation. As this phenomenon highly impacts their functionality, it is of utmost importance to increase the heat stability of whey proteins to broaden their application in the food industry, which requires a thorough knowledge of the heat stability properties of whey proteins.

\section{Scope and Approach}

To better understand the heat stabilizing activity of whey protein-polysaccharides conjugates, studies on the heat stability of whey proteins and whey protein stabilized emulsions, as well as approaches to improve their heat stability, especially using the dry heat treatment method are reviewed.

\section{Key Findings and Conclusions}

Chemical modification by combining whey proteins and polysaccharides has been reported to successfully improve the heat stability of the obtained conjugates. Hence, this new whey proteinpolysaccharide material is promising to be used as a natural emulsifier.

Keywords:

whey proteins; dry heat treatment; polysaccharides; emulsion; heat stability; 
Journal Pre-proof

\section{Whey Protein-Polysaccharide Conjugates Obtained via Dry Heat Treatment to Improve the Heat}

\section{Stability of Whey Protein Stabilized Emulsions}

Arima Diah Setiowati ${ }^{1,2}$, Wahyu Wijaya ${ }^{1}$, Paul Van der Meeren ${ }^{1}$

${ }^{1}$ Particle and Interfacial Technology group, Department of Green Chemistry and Technology, Faculty of Bioscience Engineering, Ghent University, Coupure Links 653, 9000, Gent, Belgium

${ }^{2}$ Department of Food and Agricultural Product Technology; Faculty of Agricultural Technology, Universitas Gadjah Mada, Jl. Flora No. 1, Bulaksumur, Kabupaten Sleman, Yogyakarta, Indonesia

\section{Introduction}

Dairy proteins are one of the main sources of proteins. Caseins and whey proteins are two major groups of milk proteins which have been studied intensively. Caseins are obtained after precipitation at $\mathrm{pH} 4.6$ and exist as colloidal protein aggregates, indicated as casein micelles, with high nutrient value and functionality (Zayas, 1997). In this review, the focus is given to the whey protein fraction, the second most known group of milk proteins which is famous due to its diverse functional and nutrient properties.

Due to their diverse functionality, whey proteins have been widely used as ingredients in different types of traditional and novel foods. The functional properties of whey proteins include gelling (Kharlamova, Nicolai, \& Chassenieux, 2018), emulsification (Damodaran, 2005; Ozturk \& Mc Clements, 2016), and foaming (Damodaran, 2005; Murray, Durga, Yusoff, \& Stoyanov, 2011). Among the functional properties of whey proteins, its role as a natural emulsifier has been widely recognized. Due to their amphiphilic nature, whey proteins are often used to stabilize emulsions, especially oil in water (O/W) emulsions. Whey proteins are highly soluble in the aqueous phase and able to diffuse rapidly to the oil-water interface, where they become adsorbed. This is then followed by unfolding and formation of an interfacial film around the oil droplets, which stabilizes them. Hence, whey proteins rearrange their structure upon emulsification, so that the hydrophobic part is anchored in the oil phase, while the hydrophilic groups are located in the aqueous phase, leading to 
the combined electrostatic and steric stabilization of the oil droplets (de Oliveira, Coimbra, de Oliveira, Zuñiga, \& Rojas, 2016; Oliver, Melton, \& Stanley, 2006).

The functionalities of whey proteins are highly influenced by several factors, such as the intrinsic physiological properties of the native proteins (i.e. their amino acid composition and their sequence), the ratio of hydrophobicity to hydrophilicity, charge distribution, and flexibility (Zayas, 1997). Native whey proteins have a high solubility as a result of the large number of surface hydrophilic residues. In addition, external factors such as processing conditions applied to obtain whey proteins, isolation methods, protein content, $\mathrm{pH}$, temperature and ionic strength, as well as the interaction with other food ingredients also influence the functional properties of whey proteins by changing their conformation (Zayas, 1997).

Whey proteins have been used in many food applications including sport beverages, liquid meat replacements, ice cream, salad dressing, bakery products, infant foods and various other dairy products (Wagoner \& Foegeding, 2017). However, the drawback of using whey proteins on industrial scale is their thermal instability (Ryan, et al., 2012). Heat treatment such as pasteurization and sterilization are normally used to prolong the shelf life of food products. Despite having an excellent functionality, whey proteins are very susceptible to heat induced denaturation and polymerization which lead to the reduction of their solubility and functionality (Kessler \& Beyer, 1991). A biopolymer should be highly soluble in the aqueous medium in order to provide an ideal steric stabilization. Therefore, since the functionality of proteins is highly influenced by their solubility (Zayas, 1997), it is important that whey proteins can maintain their solubility even after heat treatment. Furthermore, heat induced denaturation and aggregation alter the quality of the products containing whey proteins, which is highly undesirable. Due to its heat lability, protein aggregation takes place during heating, increasing the droplet size and viscosity of whey protein stabilized emulsions (Drapala, Auty, Mulvihill, \& O'Mahony, 2016). This phenomenon is the biggest challenge for whey protein 
applications in food industry since heat treatment is almost inevitable. Hence, in order to broaden the application of whey proteins, it is of utmost importance to improve their heat stability.

\section{Heat stability of whey proteins}

Whey proteins consist of $\alpha$-lactalbumin, $\beta$-lactoglobulin, immunoglobulins, and bovine serum albumin (BSA), which constitute $22 \%, 60 \%, 9 \%$ and $5.5 \%$ of the total whey proteins, respectively (Bryant \& Mc Clements, 1998). Furthermore, other minor compounds are also present, for instance proteose peptone, lactoferrin, lactoperoxidase and lysozyme (Walstra, Wouters, \& Geurts, 2006). The individual proteins present in whey proteins possess a different sensibility towards heat. In this part, their heat stability properties are briefly discussed.

$\beta$-lactoglobulin is the dominant protein found in whey proteins; it has a molecular weight of approximately $18.3 \mathrm{kDa}$. The secondary and tertiary structure of $\beta$-lactoglobulin consist of $43-50 \%$ of $\beta$-sheet, $10-15 \%$ of $\alpha$ helix, and $15-20 \%$ of $\beta$-turn (Cayot \& Lorient, 1997). The $\beta$-lactoglobulin conformation is $\mathrm{pH}$-dependent; it exists as a monomer at acidic $\mathrm{pH}(<3)$ and as a dimer at $\mathrm{pH}$ between 5 and 8 (deWit \& Klarenbeek, 1984; Vardhanabhuti \& Foegeding, 2008). It associates to octamers at $\mathrm{pH}$ below 2 or above 8 . By increasing the temperature, the equilibrium will shift to monomers, which is a prerequisite for heat induced aggregation (Hoffmann \& van Mil, 1999). The presence of a free thiol group in $\beta$-lactoglobulin plays an essential role in the thermal destabilization of whey proteins (Hoffmann \& van Mil, 1999). Furthermore, $\beta$-lactoglobulin can also interact with caseins through intermolecular disulphide bonds during milk heat treatment (Anema \& Li, 2003), which leads to protein aggregation. At $\mathrm{pH}$ values above 9 , reversible denaturation of $\beta$-lactoglobulin takes place (Cayot and Lorient, 1997). In milk, it was found that $\beta$-lactoglobulin denatured much faster than $\alpha$-lactalbumin (Vasbinder, van Mil, Bot, \& de Kruif, 2001). Heating of $\beta$-lactoglobulin at $80^{\circ} \mathrm{C}$ and neutral $\mathrm{pH}(6-7)$ for 20 minutes caused $80 \%$ of the protein to denature (Law \& Leaver, 2000). $\beta$-lactoglobulin is $\mathrm{pH}$-sensitive and has an Isoelectric Point (IEP) at approximately 4.0 to 5.2 (Bryant \& Mc Clements, 1998; Kováčová, Synytsya, \& Štětina, 2009). At pH-conditions around its IEP, 
$\beta$-lactoglobulin produces aggregates with a size of $2000-2500 \mathrm{~nm}$ and has a very low solubility (Kováčová et al., 2009).

$\alpha$-lactalbumin has a molecular weight of $14.2 \mathrm{kDa}$ (Jambrak, Mason, Lelas, Paniwnyk, \& Herceg, 2014). The IEP of a-lactalbumin is located at pH 4.8-5.1 (Bryant \& McClements, 1998). $\alpha$-lactalbumin is highly water soluble even at its IEP due to the presence of a high amount of hydrophilic groups and calcium $\left(\mathrm{Ca}^{2+}\right)$, which leads to its incapability to precipitate from milk at its IEP (Lucena, Alvarez, Menéndez, Riera, \& Alvarez, 2007). Furthermore, its structure exhibits a great flexibility and recovery of the native conformation due to its $\mathrm{Ca}^{2+}$ binding properties and the low degree of ordered secondary structure (Cayot \& Lorient, 1997). Upon heating of pure $\alpha$-lactalbumin, cleavage of the disulphide bond in the $\alpha$-lactalbumin structure occurs, resulting in the formation of dimers (Wijayanti, Bansal, Sharma, \& Deeth, 2014). Despite having a lower denaturation temperature $\left(62^{\circ} \mathrm{C}\right)$ compared to $\beta$-lactoglobulin, $\alpha$-lactalbumin is less heat labile (Bryant \& Mc Clements, 1998; Law \& Leaver, 2000). The heat stability of $\alpha$-lactalbumin is due to the absence of a free thiol group (deWit \& Klarenbeek, 1984). $\alpha$-lactalbumin does not undergo protein aggregation when it is heated alone. However, aggregates are formed when it is heated in the presence of $\beta$-lactoglobulin. Since $\alpha$ lactalbumin does not have any free thiol groups, it requires a free thiol group to aggregate, which in this case is provided by $\beta$-lactoglobulin (McGuffey, Otter, van Zanten, \& Foegeding, 2007). Since thiol groups are also found in BSA, the presence of BSA has the same effect on the heat stability of $\alpha$ lactalbumin (McGuffey, Otter, van Zanten, \& Foegeding, 2007). Furthermore, the presence of $\mathrm{Ca}^{2+}$ ions also contributes to the heat stability of $\alpha$-lactalbumin since the energy required to break the bonding is high. In fact, in the absence of $\mathrm{Ca}^{2+}$ ions, the heat stability of $\alpha$-lactalbumin is comparable to that of $\beta$-lactoglobulin (Haque, Aldred, Chen, Barrow, \& Adhikari, 2013).

Bovine serum albumin (BSA) of milk is physically and immunologically similar to blood serum albumin. Bovine Serum Albumin has 17 intramolecular disulfide bonds and one free sulfhydryl group (Xia et al., 2015). BSA has 582 amino acid residues with a molecular weight of about $66 \mathrm{kDa}$. The IEP 
of BSA is reported to be at pH 4.8-5.1 (Bryant \& Mc Clements, 1998). BSA has a relatively low denaturation temperature of $64^{\circ} \mathrm{C}$ (Bryant \& Mc Clements, 1998). Fatty acids were reported to provide stabilization of BSA against heat denaturation (deWit \& Klarenbeek, 1984). BSA is a wellknown whey protein for its gelling properties. During gelation of BSA, the amount of $\beta$-sheet, which is very low in the native form, increases while the amount of the $\alpha$-helix decreases. This transition is particularly critical in the gelation of BSA (Wijayanti, Bansal, \& Deeth, 2014).

The other minor proteins present in whey proteins are immunoglobulins (Ig), which are glycoproteins with antibody properties (Cayot \& Lorient, 1997). IgG, IgA and IgM are the main immunoglobulins in bovine milk and whey (deWit \& Klarenbeek, 1984). The most heat sensitive immunoglobulin is IgM, whereas the most heat resistant type is IgG (Paul, McSweeney, \& Patrick, 2013). Despite having a higher denaturation temperature compared to $\beta$-lactoglobulin and $\alpha$-lactalbumin, the presence of $B S A$ reduces the heat stability of immunoglobulins due to interaction of the free thiol group of BSA with immunoglobulins (Cayot \& Lorient, 1997).

For equivalent heating times, the heat instability of whey proteins is in the order of immunoglobulins $>$ serum albumin/lactoferrin $>\beta$-lactoglobulin $>\alpha$-lactalbumin (Law \& Leaver, 2000). Since $\beta$ lactoglobulin is the major component of whey proteins, its properties tend to dominate the properties of whey proteins including the heat stability properties (Dissanayake \& Vasiljevic, 2009). Therefore, it is reasonable to compare the behavior of whey protein isolate (WPI) during heating to that of $\beta$-lactoglobulin. The denaturation temperature of $\beta$-lactoglubulin is also often used to represent the denaturation temperature of whey proteins (Law \& Leaver, 2000). Interestingly, $\beta$ lactoglobulin alone is more stable to heat than in WPI (Ryan et al., 2012). Studies on the heat stability properties of whey proteins are summarized in Table 1. 
Table 1. Overview of studies on the heat stability of whey proteins

\begin{tabular}{|c|c|c|}
\hline Whey Protein & Variables & Investigators \\
\hline \multirow[t]{8}{*}{$\beta$-lactoglobulin } & Heat stability as a function of $\mathrm{pH}$ & $\begin{array}{l}\text { Hoffmann and van Mil (1999); Law and Leaver } \\
\text { (2000) }\end{array}$ \\
\hline & Interaction of $\beta$-lactoglobulin with caseins & $\begin{array}{l}\text { Anema and Li (2003); Kehoe and Foegeding } \\
\text { (2014) }\end{array}$ \\
\hline & $\begin{array}{l}\text { Kinetics of } \beta \text {-lactoglubulin heat } \\
\text { denaturation }\end{array}$ & $\begin{array}{l}\text { Verheul, Roefs, and de Kruif (1998); Zúñiga, } \\
\text { Tolkach, Kulozik, and Aguilera (2010) }\end{array}$ \\
\hline & $\begin{array}{l}\text { Study of } \beta \text { lactoglobulin aggregation using } \\
\text { dynamic light scattering }\end{array}$ & $\dot{\bar{\prime}}$ \\
\hline & $\begin{array}{l}\text { Simulation of } \beta \text {-lactoglobulin heat } \\
\text { denaturation in plate heat exchanger }\end{array}$ & Bouvier et al. (2014) \\
\hline & Heat denaturation at $75^{\circ} \mathrm{\epsilon}$ & $c^{2}$ \\
\hline & $\begin{array}{l}\text { Effect of dextran sulfate, } \mathrm{NaCl} \text {, and initial } \\
\text { concentration }\end{array}$ & Vardhanabhuti and Foegeding (2008) \\
\hline & Influence of minerals & Martins et al. (2016) \\
\hline \multirow[t]{5}{*}{$\alpha$-lactalbumin } & $\begin{array}{l}\alpha \text {-lactalbumin heat induced denaturation } \\
\text { and aggregation in the presence of } \beta \text { - } \\
\text { lactoglobulin, at neutral pH }\end{array}$ & $\begin{array}{l}\text { McGuffey et al. (2007); Wijayanti, Bansal, } \\
\text { Sharma, et al. (2014) }\end{array}$ \\
\hline & $\begin{array}{l}\text { Effect of dextran sulfate, } \mathrm{NaCl} \text {, and initial } \\
\text { concentration }\end{array}$ & Vardhanabhuti and Foegeding (2008) \\
\hline & Heat denaturation in the presence of BSA & \\
\hline & $\begin{array}{l}\text { Heat denaturation and aggregation at } \\
\text { neutral pH }\end{array}$ & AcGuffey et al. (2007) \\
\hline & Infant milk & $\begin{array}{l}\text { Crowley, Dowling, Caldeo, Kelly, and O'Mahony } \\
\text { (2016); Buggy, McManus, Brodkorb, Mc Carthy, } \\
\text { and Fenelon (2017) }\end{array}$ \\
\hline BSA & Heat stability and gelling properties & $\begin{array}{l}\text { Yohannes et al. (2010); Lu et al. (2015); Nikolaidis } \\
\text { and Moschakis (2017) }\end{array}$ \\
\hline
\end{tabular}

\section{Heat induced denaturation and aggregation of whey proteins}

128 Heat treatment causes changes in the conformation of whey proteins. When whey proteins are

129 exposed to heat, changes in the size of the whey proteins are observed. This might occur due to the

130 loss of cavity volumes which reduces the stability of the hydrophobic core of the globular structure

131 (Dissanayake \& Vasiljevic, 2009). In addition, changes in hydrophobic, electrical, and structural

132 properties which reduce the solubility and functionality of proteins are also observed (Wijayanti,

133 Brodkorb, Hogan, \& Murphy, 2019). 
Heat treatment of whey proteins at temperatures below $60{ }^{\circ} \mathrm{C}$ induces reversible denaturation of the protein structure which involves a partial loss of the tertiary structure (deWit \& Klarenbeek, 1984). When heated at temperatures above their denaturation temperature $\left(>70^{\circ} \mathrm{C}\right)$, whey proteins start to denature easily (Vasbinder et al., 2001). This process is even more rapid in the presence of water (Haque et al., 2013). On the other hand, in an environment with low water content, protein unfolding is probably reduced due to the low protein mobility (Gulzar, Bouhallab, Jeantet, Schuck, \& Croguennec, 2011). Therefore, the denaturation temperature of WPI in a powder form is higher than in a solution (Gulzar et al., 2011).

Protein aggregation is mainly due to a combination of non-covalent interactions such as Van der Waals attraction forces, hydrophobic interaction, and electrostatic interaction (Pelegrine \& Gasparetto, 2005). Initially, before heating, proteins exist as dimers and monomers in which upon heating the equilibrium is shifted to the monomers (Nicolai, Britten, \& Schmitt, 2011). When heating is performed at temperatures above the denaturation temperature of the whey proteins, it results in the disruption of their native structure (Kessler \& Beyer, 1991). At this stage, the secondary and tertiary structure of whey proteins become unfolded, exposing reactive amino side groups and hydrophobic groups (-SH groups) which are normally buried (Anema \& Li, 2003; Pelegrine \& Gasparetto, 2005). This is also accompanied by the increased reactivity of the free thiol groups of whey proteins (Anema \& Li, 2003). The exposed thiol groups in the newly formed monomers are able to form disulfide linkages by thiol/disulfide exchange reactions with other molecules (Hoffmann \& van Mil, 1999). Due to this covalent interaction, a small amount of oligomers (mainly dimers and trimers) is formed. Above a certain critical association concentration of oligomers, they associate and form protein aggregates (primary aggregates) (Nicolai et al., 2011). This critical association concentration is highly influenced by the $\mathrm{pH}$ and ionic strength. The aggregates formed during heating are stable at lower protein concentrations, but associate into larger clusters or even a gel at higher concentrations (Brodkorb, Croguennec, Bouhallab, \& Kehoe, 2016; Nicolai et al., 2011). Nicolai et al. (2011) stated that the size of the aggregates got bigger at lower $\mathrm{pH}$ and higher ionic strength. A 
schematic image of $\beta$-lactoglobulin aggregation can be found in Figure 1. The role of non-covalent interactions in aggregation of $\beta$-lactoglobulin is more significant at higher temperatures (Vardhanabhuti \& Foegeding, 2008). Their contribution in aggregation and gelation processes is determined by environmental conditions, such as $\mathrm{pH}$, temperature and salt concentration (Brodkorb et al., 2016; Vardhanabhuti \& Foegeding, 2008).

165

To summarize, the processes involved in aggregate formation are (1) chemical aggregation through exchange reactions between thiol groups and disulfide bonds, (2) physical aggregation of unfolded protein molecules or chemically formed aggregates, or (3) a complex combination of chemical and physical aggregation (Verheul et al., 1998). However, the nature of cross-linking between proteins in the aggregates is not known at a molecular level (Nicolai et al., 2011). These authors suggested that it might involve hydrophobic and hydrophilic interactions, hydrogen bonding, and disulfide bonds. The latter is applicable at pH-conditions above the IEP of $\beta$-lactoglobulin (Nicolai et al., 2011).

At neutral $\mathrm{pH}$ and intermediate temperature $\left(65^{\circ} \mathrm{C}\right)$, Roef and de Kruif (1994) proposed that heat induced denaturation of proteins occurs in three stage namely: initiation, propagation, and termination. Initiation takes place when free thiol groups are available in the system. Propagation follows when these free thiol groups react with disulfide bonds resulting in a new free thiol group. This sequence of reactions ends when there is a lack of thiol groups due to the association of aggregates into bigger structure (polymerization) (Ryan, Zhong, \& Foegeding, 2013).

In milk, the behavior of $\beta$-lactoglobulin during heating is also affected by the presence of caseins. It was found that the reaction order of $\beta$-lactoglobulin denaturation in skim milk was different from that in whey protein solution: whereas in skim milk solutions the order of reaction of $\beta$-lactoglobulin denaturation was 1.5 , in whey the reaction order of $\beta$-lactoglobulin denaturation was reported to be 2.0 (Kessler \& Beyer, 1991). The possible explanation was that there was an influence of the caseins present in skim milk. The heated $\beta$-lactoglobulin is able to interact with $\mathrm{k}$-casein at the periphery of the casein micelles through disulfide bonds leading to the disruption of the casein micelles properties 
(Vasbinder et al., 2001). In the presence of caseins, $\beta$-lactoglobulin denatures to a greater extent (Kessler \& Beyer, 1991).

For the sake of completeness, it has to be mentioned that heat treatment does not always have a negative impact as long as it is well controlled. For some cases, the changes that take place in whey proteins after heat treatment, such as partial denaturation, formation of soluble aggregates, or gelling of the proteins after heating, are in fact desirable. Soluble aggregates of whey proteins formed by controlled heating $\left(90^{\circ} \mathrm{C}\right.$ for 10 minutes) have been found to have a better heat stability than native whey proteins which is attributed to the higher overall negative charge density, the smaller size, and the more compact structure (Ryan et al., 2012). By controlling the denaturation rate, $\mathrm{pH}$, and ionic strength, a gel can also be obtained which is beneficial to provide a desirable texture. Astrong and elastic gel has been obtained by heating whey protein solutions at $85^{\circ} \mathrm{C}$ and $\mathrm{pH}$ of 7.5 (Shimada \&Cheftel, 1989). Adding of salt, such as $\mathrm{CaCl}_{2}$, enables the formation of a gel at a lower temperature (Kharlamova et al., 2018). Disulfide bonds due to sulfhydryl groups and disulfide bridge interchange reactions were mentioned to be responsible for the formation of the gel network obtained from the heated whey proteins (Brodkorb, Croguennec, Bouhallab, \& Kehoe, 2016). It is the same mechanism which is also responsible for the aggregation of whey proteins during heating.

\section{Influence of heat treatment on whey proteins stabilized emulsions}

The heat stability of whey protein stabilized emulsions is obviously influenced by the heat stability of the whey proteins. In whey protein stabilized emulsions, the droplet size of the emulsion increases as heat induced denaturation and aggregation take place and reaches a maximum diameter. The higher the temperature, the sooner the maximum diameter is reached (Sliwinski, Roubos, Zoet, van Boekel, \& Wouters, 2003). During heating of emulsions, three possible associations can occur, namely droplet-droplet interaction, protein-protein interaction, and protein-droplet interaction (Euston, Finnigan, \& Hirst, 2000). These authors stated that, upon heating, protein-droplet interaction was 
more favourable than droplet-droplet interaction since the denatured non-adsorbed whey proteins

have a higher hydrophobicity than the droplets surface (Euston et al., 2000).

211

The rate of droplet flocculation in emulsions was reported to reach a maximum at temperatures around $65-80^{\circ} \mathrm{C}$ and decrease upon further heating (Demetriades, Coupland, \& McClements, 1997). A possible explanation is that at lower temperature the partially unfolded proteins cannot effectively arrange their hydrophobic groups on the oil phase which increases the hydrophobicity of the surface of the oil droplets leading to flocculation. In contrast, at higher temperature the fully unfolded protein is able to arrange the hydrophobic groups to be fully attached on the oil droplet. Therefore, the surface of the oil droplets is less hydrophobic and the tendency of the oil droplets to aggregate is lower (Demetriades et al., 1997). Rearrangement of the aggregates takes place upon further heating which converts loose aggregates to smaller and more compact aggregates. This rearrangement can be explained by the increase of the number of contacts between proteins in the aggregates while at the same time the amount of available protein which has contact with the protein decreases (Sliwinski et al., 2003). In emulsions, the amount of unadsorbed protein is important. Heating of oil in water emulsions results in the unfolding of non-adsorbed whey proteins exposing their hydrophobic groups which then induce association of the unadsorbed proteins with the adsorbed whey proteins on the surface of the oil droplets. These unfolded proteins act as a glue in between the oil droplets by associating with more than one droplet creating droplet flocculation and aggregation (Fig. 2) (Euston et al., 2000). Preventing droplet aggregation in heated emulsions is important. Droplet aggregation in heated emulsions increases the viscosity of these emulsion (Drapala et al., 2016), which alters the rheological properties of the products. In severe cases, a gel is formed upon heating of whey protein stabilized emulsions. For beverage production and in the milk industry, this phenomenon is highly undesirable. Hereby, the concentration of whey proteins in the emulsion and the heating conditions are very important in determining the rheology and stability of the heated emulsion (Sliwinski et al., 2003). Whey protein stabilized emulsions are considered to be heat stable if the emulsions can maintain their original consistency after heat treatment. 
In order to obtain heat stable whey proteins with improved functional properties, modification of the molecular structure of the whey proteins can be performed. Steric, electrostatic, and hydrophobic properties are important to maintain the solubility of heated proteins. These factors can be taken into account for selecting a method to be used for modifying the structure of the whey proteins.

Several methods have been proposed to modify the structure of proteins in order to improve their heat stability, including physical modification, enzymatic modification, and chemical modification (Wijayanti et al., 2019). Physical modification of proteins can be performed by partial denaturation of the proteins or protein unfolding to increase the hydrophobicity of the proteins (Lam \& Nickerson, 2015). This can be performed by exposing the proteins either to heat or to a high hydrostatic pressure under controlled heating and shear conditions. However, this method does not completely solve the problems since the partially denatured proteins are still sensitive to heating and $\mathrm{pH}$. Furthermore, the process of the partial denaturation itself is difficult to be controlled (Damodaran, 2005). In addition to thermal treatment, high pressure treatment and high-shear technology are currently gaining more attention to improve the heat stability of whey proteins (Wijayanti et al., 2019). Another alternative method is enzymatic modification of proteins via hydrolysis and polymerization. Protein hydrolysis can be performed using pepsin and trypsin, while polymerization of proteins is possible with transglutaminase (Damodaran, 2005). The latter has been applied for improving the thermal stability of whey proteins through formation of covalent cross-links between reactive proteins (Stender et al., 2018; Zhong, Wang, Hu, \& Ikeda, 2013). Chemical modification of proteins is performed by changing either the structure of the proteins at the secondary, tertiary and quaternary levels, or the hydrophobic to hydrophilic ratio (Damodaran, 2005). Acylation, phosphorylation, alkylation, sulfitolysis and the amino-carbonyl reaction are some available methods 
these methods, phosphorylation and amino-carbonyl (Maillard reaction) methods are more advisable for application in food products (Damodaran, 2005).

Besides structural modification, the heat stability of proteins can also be improved by adding compounds which can prevent protein aggregation such as dihydrolipoic acid (DHLA) or $\mathrm{N}$ ethylmaleimide (NEM). These compounds improve the thermal stability of $\beta$-lactoglobulin by blocking the reactive thiol groups preventing protein aggregation upon heating (Wijayanti, Bansal et al. 2014). However, most of these thiol blocking compounds are not food grade.

Among the available methods mentioned above, combining whey proteins with other biopolymers such as polysaccharides seems to be a promising method to improve the heat stability of whey proteins. Biopolymers such as pectin, gum Arabic, carrageenan, and other polysaccharides are all food grade and have been widely used in food applications (Wang et al., 2018). As polysaccharides are mostly hydrophilic, the presence of the hydrophilic groups from the polysaccharides might enhance the hydrophilicity of the proteins. Furthermore, due to the growing interest in natural emulsifiers, the application of this method would enable the production of "clean-label emulsions" (Ozturk \& McClements, 2016).

Combining whey proteins and polysaccharides can be performed through electrostatic interactions or Maillard type reactions. The methods used for electrostatic complexation are relatively simple (Qi, Chau, Fishman, Wickham, \& Hotchkiss Jr, 2017; Qi, Wickham, \& Garcia, 2014). Improvement of the functionality and thermal stability of whey proteins through electrostatic interaction with pectin has been previously reported (Qi et al., 2014; Wagoner \& Foegeding, 2017). However, the electrostatic complexation is highly affected by environmental conditions such as $\mathrm{pH}$, ionic strength, and temperature (Gentes, St-Gelais, \& Turgeon, 2010; Setiowati, Saeedi, Wijaya, \& Van der Meeren, 2017; Wagoner \& Foegeding, 2017). The presence of salt and a change of the pH might break or weaken the complexation between the biopolymers. Therefore, electrostatic complexes have a very narrow range of optimum $\mathrm{pH}$ and are highly sensitive to the $\mathrm{pH}$, which limits their application. 
Heating is sometimes required to stabilize the electrostatic complexes at neutral pH (Gentes et al., 2010).

In addition, despite of having a higher degree of interaction (yield), emulsions stabilized by WPI-Low Methoxyl Pectin (LMP) electrostatic complexes (formed at a pH around the IEP of WPI) were found to be less stable against creaming and heat than those stabilized by WPI-LMP conjugates produced with a Maillard type reaction (Setiowati, Rwigamba, \& Van der Meeren, 2019; Setiowati et al., 2017). Furthermore, the former had a lower emulsifying activity than the latter. Therefore, it seems that the nature of the interaction between WPI and polysaccharides is an important factor which determines the functionality of the WPI-polysaccharide conjugates.

On the other hand, the Maillard type reaction is a spontaneous and naturally occurring reaction. This process only requires the addition of polysaccharides and no additional chemicals are needed. Hence, these products can be safely incorporated into food systems without using undesirable chemical catalysts (Oliver et al., 2006). Through this method, new compounds with di-block or graft structure containing both hydrophobic and hydrophilic groups are obtained (Schong \& Famelart, 2017).

\section{Dry Heating of whey proteins and polysaccharides}

Whey proteins can be combined with other components, such as emulsifiers or thickeners to improve their functionality. Food products are composed of a wide range of ingredients such as proteins and carbohydrate-based polysaccharides (Ye, 2008). Some polysaccharides are known to have a good emulsion stabilizing activity . Whereas proteins adsorb at the oil-water interface during emulsification to form a viscoelastic layer, polysaccharides generally offer colloid stability through their thickening and gelation behavior in the aqueous phase. Combining the hydrophobic properties of proteins and the hydrophilic properties of polysaccharides has been reported to improve the functionality and heat stability of whey proteins. However, mixtures of biopolymers are often 
unstable, which leads to separation of the mixture into two phases (Ye, 2008). Thus, certain techniques to combine proteins and polysaccharides are needed in order to achieve the desirable properties and stable biopolymer complexes. This can be performed via either electrostatic interaction or conjugation by covalently linking polysaccharides to whey proteins. This review is focused on the interaction of whey proteins with polysaccharides via covalent interaction through the dry heat treatment method. Doost, Nasrabadi, Wu, A'yun, and Van der Meeren (2019) recently compared this conventional approach to novel methods, such as pulsed electric fields, sonication, extrusion, high pressure treatment, and electrospinning, to initiate covalent interaction between proteins and polysaccharides.

Whey proteins and pectin can be conjugated by applying heat to a dry mixture. In this method, the protein and the polysaccharide are heated at slightly elevated temperatures for a certain period of time to induce Maillard type reactions. This results in a glycoprotein, a compound in which the polysaccharide is covalently linked to the protein (Schong \& Famelart, 2017). Dry heat treatment of WPI and pectin induces the formation of complexes, as can be observed from the reduced amount of free amino groups, the emergence of high molecular weight components in SDS-PAGE and the decreased mobility of the whey proteins as measured by diffusion-NMR (Jiménez-Castaño, LópezFandiño, Olano, \& Villamiel, 2005; Setiowati et al., 2018; Setiowati, Vermeir, Martins, De Meulenaer, \& Van der Meeren, 2016; Wefers, Bindereif, Karbstein, \& van der Schaaf, 2018). These conjugates are formed by covalent attachment of the polysaccharides to WPI through Maillard type reactions during the dry heat treatment (Wefers et al., 2018). As conjugation largely affected the diffusion behavior of the proteins, but hardly changed the diffusivity of the pectin, it follows that complexes typically involve only 1 pectin molecule, chemically bound to either 1 or more protein molecules (Setiowati et al., 2018). No additional chemicals are needed, making this method safe for food applications (Damodaran, 2005; Kato, 2002). 
Conjugation of proteins and polysaccharides can be performed either in the wet state or dry state. In

the wet state, the protein and polysaccharide mixture are heated in solution. This method has been successfully used to improve the functionality and heat stability of proteins such as vegetable protein isolate, sodium caseinate, and whey proteins (Consoli et al., 2018; Meng, Kang, Wang, Zhao, \& Lu, 2018; Mulcahy, Mulvihill, \& O'Mahony, 2016; Pirestani, Nasirpour, Keramat, Desobry, \& Jasniewski, 2017). The drawback of this method is that there is a risk of contamination due to microbial growth (Liu \& Zhong, 2013). Furthermore, handling and storage of the liquid product are more challenging than that of dry products (Liu \& Zhong, 2013). It was also suggested that the products obtained from dry heating had a better long term stability than those obtained from wet heating (Liu \& Zhong, 2013). Regarding the impact of conjugation onto the structure of the protein, conjugation via wet state heat treatment has been found to cause important structural changes resulting in a specific denatured $\beta$-lactoglobulin monomer, which is covalently associated via the free thiol group (Morgan, Léonil, Mollé, \& Bouhallab, 1999). On the other hand, this phenomenon is restricted in dry state heat treatment (Schong \& Famelart, 2017). Xia et al. (2015) found that upon dry heating of BSA and dextran, the attachment of dextran to BSA was able to minimize the loss of its secondary and tertiary structure during dry heat treatment and to protect BSA from aggregation. Dry heat treatment of WPI with sugar beet pectin has been shown to preserve the antiparallel $\beta$-sheet element of the WPI structure (Liu \& Zhong, 2015). Hence, conjugation of proteins and polysaccharides in dry state is more preferable due to the advantages that the method offers.

Dry heat treatment is performed by heating a dry mixture of proteins and polysaccharides. Upon dry heat treatment, Maillard reactions takes place resulting in a covalently linked protein and polysaccharide conjugate (Fig. 3). To be specific, the conjugation of whey proteins and polysaccharides via dry heat treatment is basically based on the Amadori arrangement which takes place in the early stages of the Maillard reaction (Oliver et al., 2006). Hereby, the amino groups of a protein interact with the free carbonyl groups of polysaccharides (Wefers et al., 2018). The amino groups that actively participate in the Maillard reaction are mostly the $\varepsilon$-amino groups of lysine. 
However, other groups such as imidazole groups of histidine, indole groups of tryptophan, and guanidine groups of arginine are able to participate in the Maillard reaction to a lesser extent (Ames, 1998).

In general, the Maillard reaction is composed of three different stages, namely the early, intermediate/advanced, and final stage (Oliver et al., 2006). At the early stages of the Maillard reaction, carbonyl groups condense with free amino groups to form a Schiff base accompanied by water release. The Schiff base then cyclizes to the corresponding $\mathrm{N}$-glycosylamine followed by irreversible Amadori rearrangement resulting in 1-amino-1-deoxy-2-ketose (Amadori product). However, if the Maillard reaction is performed using ketose containing sugar, the reaction will follow the Heyn's rearrangement, resulting in 2-amino-2-deoxyaldose (Heyn's product) (Oliver et al., 2006). These intermediate products obtained might undergo further polymerization into brown color at the advanced and final stages of the Maillard reaction (Liu, Kong, Han, Sun, \& Li, 2014). The same authors reported that formation of these intermediate products was higher when the initial $\mathrm{pH}$ of the samples before heat treatment was more alkaline.

Following the early stage, the intermediate stage of Maillard takes place. At this stage, the Amadori or Heyn's products are transformed via different pathways depending on the $\mathrm{pH}$ of the environment (Oliver et al., 2006). The products formed in the degradation of Amadori or Heyn's products are highly reactive and able to involve in various transformation reactions such as oxidation, cyclization, hydrolysis, fragmentation, and free radical reaction. Color development has also been detected at the intermediate stage. Nevertheless, a more intensive color development takes place at the final stage of the Maillard reaction with melanoidins as the final products (Nooshkam \& Varidi, 2019). More detailed information of the chemical reactions occurring during preparation can be found in some recent reviews (Schong and Famelart, 2017; Doost et al., 2019; Nooshkam and Varidi, 2020).

In the case of protein and polysaccharide conjugation, the Maillard reaction should be well controlled to avoid the advanced stage of the Maillard reaction. The latter has been found to produce protein- 
polysaccharide conjugates with low solubility due to cross linking and polymerization, and thus exhibits poor functionality (Kato, 2002; Oliver et al., 2006). Excessive heating of WPI in the presence of a reducing sugar, such as glucose, results in advanced stage Maillard reactions which reduce the solubility of WPI (Jiménez-Castaño, López-Fandiño, et al., 2005; Setiowati et al., 2019). For food applications, conjugates with low solubility and intense brown color are undesirable (Oliver et al., 2006). The product of dry heat treatment via Maillard reaction is a hybrid compound with high molecular weight (Schong \& Famelart, 2017; Setiowati et al., 2016). This new compound (conjugate) seems to be responsible for the improved functionality and thermal stability of the conjugate.

In principle, the Maillard reaction might lead to unsafe and toxic products. Some products of the Maillard reaction have been reported to be mutagenic or carcinogenic (de Oliveira et al., 2016). However, most of these compounds are produced at the advanced stage of the Maillard reaction, while during formation of the conjugates the advanced stage of the Maillard reaction is avoided. Hence, it is expected that these toxic compounds are not formed during protein polysaccharide conjugation. Jing and Nakamura (2005) conducted a research to test the toxicity and mutagenicity of glycosylated products (protein-polysaccharide conjugates) in rats. They found that the conjugates were safe and no toxic compounds were found in the conjugates. Hence, glycosylation products prepared in well-controlled conditions are suitable for food application (de Oliveira et al., 2016; Jing \& Nakamura, 2005). Furthermore, it is worth to mention that protein-polysaccharide glycosylation has been used to reduce the allergenicity of some proteins and has shown positive results (Nakamura et al., 2008; Usui et al., 2004).

\section{Influencing factors of conjugation of proteins and polysaccharides}

In order to achieve protein-polysaccharide conjugates with optimum functionality, it is important to control the heat treatment. A good understanding of the key reaction parameters influencing the glycation and side reactions as well as their influence on the protein functionality is of utmost importance. Conjugation of proteins and polysaccharides is influenced by several factors, such as 
temperature, time, $\mathrm{pH}$, relative humidity, as well as type and concentration of protein and polysaccharide (Ames, 1998).

\subsection{Combination of time, temperature, and relative humidity $(\mathrm{RH})$ or water activity $\left(\mathrm{a}_{\mathrm{w}}\right)$}

The dry heating method involves lyophilisation of a solution of a protein and a reducing sugar or oligo/polysaccharide, which is followed by equilibration and incubation at the desired $\mathrm{a}_{\mathrm{w}}$ or RH under controlled temperature for a certain period of time (Kato, 2002). It was reported that conjugation of $\beta$-lactoglobulin and dextran at higher temperature, lower $a_{w}$ and lower ratio of $\beta$-lactoglobulin to dextran resulted in a higher formation rate of Amadori compounds which correlated with a higher degree of conjugation (Jiménez-Castaño, Villamiel, Martín-Álvarez, Olano, \& López-Fandiño, 2005). Martinez-Alvarenga et al. (2014) reported that increasing the incubation temperature from 50 to $60^{\circ} \mathrm{C}$ was able to increase the degree of conjugation from 26 to $40 \%$. Besides an increase of the reactivity of the carbonyl group and amino group by incubation at higher temperature, the authors also suggested that this could be due to the greater unfolding that occurred to the protein structure which consequently exposed a higher amount of reactive functional groups, such as lysine.

Regarding the heating time or incubation time, the duration of the incubation should be well controlled and as short as possible to prevent the reaction reaching the advanced stage and to limit the polymerization and browning (Liu \& Zhong, 2013). Furthermore, Xia et al. (2015) have reported that upon conjugation, a longer incubation time decreased the rate of dextran attachment to WPI, which might be due to the steric hindrance of the dextran which was already attached to the WPI. The optimum time for conjugate formation might differ between each process depending on the temperature and type of polysaccharide; it can range from hours to weeks. Normally, long chain polysaccharides require a longer dry heat treatment time than short chain polysaccharides and simple sugars. Conjugation of WPI and lactose has been reported to take place at $130^{\circ} \mathrm{C}$ for 2 hours (Liu \& Zhong, 2015). On the other hand, conjugation of WPI with a higher molecular weight sugar at lower temperature required a longer heating time than at higher temperature (Liu \& Zhong, 2015). 
Previously, the formation of WPI-LMP conjugates was found to be rapid during the first two days of dry heat treatment and continuously increased at a slower rate upon extending the dry heat treatment to 16 days at $60{ }^{\circ} \mathrm{C}$ (Setiowati et al., 2018; Setiowati et al., 2016). In a recent study, 3 days of dry heat treatment was found to be the optimum duration for conjugation of $\alpha$-lactalbumin and $\beta$ lactoglobulin with polysaccharides (Mulcahy et al., 2016). Nevertheless, it should be noted that a longer dry heat treatment time does not always produce conjugates with the best functionality (Chen et al., 2019). In fact, a decrease of the functionality of protein-polysaccharide conjugates upon extended dry heat treatment has been reported. Thus, longer dry heat treatment of pea protein in the presence of gum arabic decreased the solubility and emulsifying properties of the protein (Zha, Dong, Rao, \& Chen, 2019). The authors suggested that this phenomenon was caused by excessive reaction between the protein and polysaccharides. A similar phenomenon was observed by Chen et al. (2019).

It has been reported that dry heat treatment of proteins and polysaccharides was optimum at intermediate RH or $\mathrm{a}_{\mathrm{w}}$ values (Ge Pan \& Melton, 2007): at this intermediate range of RH values (3079\%), the degree of conjugation seemed to be increasing with RH (Ge Pan \& Melton, 2007; MartinezAlvarenga et al., 2014), whereas the degree of conjugation decreased with RH outside this range of RH values (e.g. $\geq 80 \%$ ) (Ge Pan \& Melton, 2007). Conjugation of proteins and polysaccharides was also reported to be optimum when it was performed at a $\mathrm{RH}$ of $65 \%$ and $79 \%$ (Kato, 2002). As a further consequence, these $\mathrm{RH}$ values are most commonly used for conjugate preparation (de Oliveira et al., 2016). According to other authors, the optimum $a_{w}$ for the Maillard reaction is located between 0.5 and 0.8 (Oliver et al., 2006). However, a wider range of optimum $a_{w}$ values for Maillard reaction was reported by Martinez-Alvarenga et al. (2014): in their study, the optimum $a_{w}$ was observed to be in between 0.3 and 0.8 . These phenomena can be explained by the impact of the water activity on the concentration and mobility of the reactants (Cheison \& Kulozik, 2017). At higher $a_{w}$, the reactants are too diluted, and thus the conjugation rate is lower (Cheison \& Kulozik, 2017). On 
the other hand, at a very low $a_{w}$, the mobility of the reactant is too restricted (Martinez-Alvarenga et al., 2014) and as a consequence the conjugation is limited.

\subsection{Type of polysaccharide}

The type of polysaccharide highly influences the functionality and heat stability of the conjugates since steric stabilization was reported to play an important role in the functionality and heat stability of the conjugates. The functionality of proteins decreases when a high amount of carbonyl groups is attached to the amine groups of the proteins (Kato, 2002). Furthermore, the advanced stage of the Maillard reaction has been found to highly reduce the solubility of the conjugate (Kato, 2002; Setiowati et al., 2019). This is undesirable since the functionality of proteins is largely affected by their solubility. This phenomenon has a higher possibility to take place when the conjugation is performed with monosaccharides as well as oligosaccharides (Kato, 2002). In addition, when short chain polysaccharides or polysaccharides rich in reducing sugars are used, the reaction should also be strictly controlled to prevent the advanced stage of the Maillard reaction in which polymerization and browning dominate (Aoki et al., 1999). Polysaccharides are less reactive than monosaccharides, and thus the advanced and final stage of the Maillard reaction can be more easily prevented. It was found that the brown color development and protein polymerization during Maillard reaction were suppressed when conjugation was performed with long chain polysaccharides (Aoki et al., 1999). Furthermore, the longer the chain of the polysaccharides, the better the emulsifying activity of the conjugates will be (Shu, Sahara, Nakamura, \& Kato, 1996). Hence, conjugation of proteins with polysaccharides is found to be more interesting for industrial application (Kato, 2002). As far as the molecular weight is concerned, it was reported that whey proteins conjugated with lower molecular weight dextrans underwent more structural changes than those with higher molecular weight dextran (Spotti et al., 2014). Kato (2002) found that saccharides with a molecular weight of at least $10 \mathrm{kDa}$ are suitable to be conjugated with proteins as they are able to increase the functionality of the proteins as emulsifier. In general, polysaccharides and sugar with a larger molecular size are more preferable for conjugation via dry heat treatment as they provide more steric hindrance (Chen, 
Chen, Guo, \& Zhou, 2015). This is beneficial for the stability of the protein, as well as of the emulsion

485

486

487

488

489

490

491

492

493

494

495

496

497

498

499

500

501

502

503

504

505

506

507

508

stabilized by the conjugates. Furthermore, polysaccharides with negative charges are also preferable as they have the ability to increase the surface charge density and prevent the formation of aggregates during heating due to electrostatic repulsion (Chen et al., 2015). However, it should be kept in mind that dry heat treatment of proteins with high molecular weight polysaccharides lowers the conjugation rate due to steric hindrance (ter Haar, Schols, \& Gruppen, 2011; Xia et al., 2015). Charged polysaccharides may exhibit the same behavior due to electrostatic repulsion instead of steric hindrance (ter Haar et al., 2011).

Long chain and high molecular weight polysaccharides that can be utilized include pectins, gums, dextrans, and galactomannans. Whey proteins have been reported to be thermodynamically compatible with pectin, which is important to obtain optimal conjugation (Einhorn-Stoll, Ulbrich, Sever, \& Kunzek, 2005). Due to their compatibility, the whey proteins and pectin will be in close contact upon mixing and will form a homogeneous mixture of the biopolymers, thus promoting better conjugation (Einhorn-Stoll et al., 2005). With regard to pectin, previous research showed that conjugation with pectin with a high degree of methylation (DM) slightly improved the emulsifying activity of whey proteins (Einhorn-Stoll et al., 2005). In contrast, Schmidt et al. (2016) and Setiowati et al. (2019) reported that the DM did not influence the performance of the resulting conjugates. However, the former suggested that the use of pectin with low DM is more advisable since a higher yield was obtained from the dry heat treatment. Furthermore, polysaccharides with higher Dextrose Equivalent (DE) values resulted in more extensive conjugation than those with lower DE values (Mulcahy et al., 2016).

The presence of sugar, in particular dextrose, was reported to interfere with the formation of conjugates during dry heat treatment. It was observed that advanced Maillard reaction between dextrose present in a commercial HMP sample with WPI took place at longer dry heat treatment times which led to browning and polymerization of the protein. As a consequence, a reduction of the 
functionality of the WPI was observed (Setiowati et al., 2019). Hence, dry heat treatment in the presence of reducing sugars should be well controlled.

\section{Improved functional activity of conjugated whey proteins}

Glycation of proteins, as well as conjugation of proteins and polysaccharides via the Maillard reaction influences the functional properties of proteins by changing their charge, solvation, and conformation (Oliver et al., 2006). The functional properties of the protein-polysaccharide conjugates are remarkably different from the original biopolymers.

\subsection{Emulsifying activity of Whey Protein-Polysaccharides conjugates}

In addition to heat stability, conjugation of whey proteins also improves their emulsifying properties. The excellent emulsion stability offered by protein-polysaccharide conjugates is due to the fact that the biopolymers work synergistically to stabilize the emulsion. Upon emulsification, the protein moieties of the conjugates are adsorbed onto the oil-water interface (Kato, 2002) and thus polysaccharides are carried by the protein and become available on the surface of the oil droplets. The latter is not possible, or only to a very limited extent, when the polysaccharides are not conjugated to the protein. Upon adsorption, the hydrophobic groups of the protein are anchored onto the oil droplets while the hydrophilic groups of the polysaccharides orient themselves in the aqueous phase (de Oliveira et al., 2016). Protein-polysaccharide conjugates stabilize the emulsion through a steric hindrance effect which inhibits recoalescence of oil droplets during emulsification (de Oliveira et al., 2016) resulting in a smaller droplet size. Polysaccharides provide a protective viscoelastic layer which enhances the stability of the emulsion over time (Kato, 2002). Furthermore, the presence of additional hydrophilic groups from the polysaccharides increases the hydrophilicity of the oil droplets in the emulsion, which also enhances the stability of the emulsions (Akhtar \& Dickinson, 2007). In addition to the steric stabilization, the charge of the conjugates also plays an important role in stabilizing the conjugates. It was reported that dry heat treatment of WPI and LMP was very effective to improve the heat stability of WPI and the emulsifying activity of WPI stabilized 
emulsions around its IEP, which is attributed to the downward shift of the IEP of the protein upon binding with the anionic pectin molecules (Setiowati et al., 2017). Thus, the stabilizing activity of protein-polysaccharide conjugates is due to a combination of steric and electrostatic stabilization.

The emulsifying activity of the WPI-polysaccharide conjugates is significantly improved compared to that of native WPI, especially around the protein's IEP. Setiowati et al. (2017) observed that the droplet size of the emulsions decreased considerably when the WPI-LMP mixture was dry heat treated for 1 day and continuously decreased slightly as the dry heat treatment time was prolonged.

The same trend was also observed when the concentration of LMP in the conjugates was increased. This indicated that the emulsifying activity of the WPI-LMP conjugates might be related to the yield of the conjugation reaction, as longer dry heat treatment and higher pectin concentration led to a higher conjugation yield (Setiowati et al., 2018; Wefers et al., 2018). Conjugates with a higher yield of conjugation (higher degree of interaction) resulted in a higher emulsifying activity. On the other hand, dry heating of WPI in the absence of polysaccharides did not significantly influence the functional properties of WPI. This showed that the improvement of the heat stability and emulsifying activity of the WPI was solely due to the presence of WPI-LMP conjugates.

In contrast to WPI-pectin conjugates, simple mixing of WPI with LMP (leading to electrostatic complexes) only improved the emulsifying activity and heat stability of WPI, provided that the environmental conditions favoured electrostatic interaction, i.e. at a $\mathrm{pH}$ that limits electrostatic repulsion (close to IEP), as well as low salt concentration (Setiowati et al., 2017). In addition, the performance of these complexes was highly influenced by the concentration of pectin, $\mathrm{pH}$, and presence of salt (Chen et al., 2018; Setiowati et al., 2017).

\subsection{Heat stability of Whey Protein-Polysaccharides conjugates}

To improve the heat stability of whey proteins, it is necessary to prevent their unfolding and/or the association of the unfolded whey proteins. In $\mathrm{O} / \mathrm{W}$ emulsion systems, whey protein-pectin conjugates successfully improved not only the emulsifying activity, but most importantly, also the 
heat stability of the WPI (Setiowati et al., 2016), as well as of the WPI stabilized emulsion (Setiowati et al., 2017): aqueous solutions of WPI-LMP conjugates were stable against heat and no visible aggregates were observed in the solutions upon heating. The effectiveness of dry heat treatment in improving the heat stability of proteins has been reported in several other studies (Chen et al., 2019; Chen et al., 2015; Jiménez-Castaño, López-Fandiño, et al., 2005; Mulcahy et al., 2016; Wang \& Ismail, 2012; Zha et al., 2019).

Compared to protein-polysaccharide complexes obtained from electrostatic interaction, proteinpolysaccharide conjugates obtained from dry heat treatment are superior. The proteinpolysaccharide complexes formed via Maillard type reactions are more stable at a wider range of pH values and various ionic strengths without precipitation as compared to those obtained from electrostatic interaction (Jiménez-Castaño, López-Fandiño, et al., 2005; Mulcahy et al., 2016). Furthermore, conjugation of proteins and polysaccharides reduces the sensitivity of the protein to $\mathrm{pH}$ due to the alteration of the net charge on the protein molecules which causes changes in the nature and magnitude of the intermolecular forces between protein molecules (Chen et al., 2015). It has been reported that whey proteins become heat stable at a $\mathrm{pH}$ around their IEP in the presence of 30 mM salt upon complexation with pectin (Jiménez-Castaño, López-Fandiño, et al., 2005; Setiowati et al., 2016). Moreover, upon conjugation with anionic polysaccharides, the overall net charge of the conjugates is shifted to more negative values since there is a reduction of the number of lysine residues which is the contributor of positive charges (Liu \& Zhong, 2013).

Similarly, emulsions stabilized by WPI-pectin conjugates were reported to be able to withstand heating at 80 and $120^{\circ} \mathrm{C}$ in the presence and absence of $30-50 \mathrm{mM} \mathrm{NaCl}$ (Mulcahy et al., 2016; Setiowati et al., 2017). Furthermore, despite of the fact that WPI-pectin conjugates which were dry heat treated for only 1 day had a lower yield than those dry heat treated for 16 days, the heat stability of these two conjugates was comparable (Setiowati et al., 2017; Setiowati et al., 2018). Thus, the heat stabilizing activity of the conjugates is not influenced by the yield or degree of interaction to 
a large extent. According to Mulcahy et al. (2016) and Zha et al. (2019), heat induced droplet flocculation in emulsions stabilized by protein-polysaccharide conjugates was prevented due to the improved hydrophilicity and steric interaction on the surface of oil droplets provided by the attached polysaccharides.

In addition, the heat stability of emulsions stabilized by WPI-pectin conjugates was better than that of emulsions stabilized by WPI only, WPI-pectin mixtures, and by WPI-pectin complexes obtained via electrostatic interaction at pH 5 (Qi, Xiao, \& Wickham, 2017; Setiowati et al., 2017). Emulsions stabilized by WPI-pectin conjugates were able to retain their initial consistency and droplet size after heating (Fig. 4). On the other hand, emulsions stabilized by native WPI or by a mixture of WPI-LMP (without dry heat treatment) formed droplet aggregates (Fig. 4).

The heat stability of emulsions stabilized by whey protein-polysaccharide conjugates can also be attributed to the prevention of unadsorbed protein aggregation during heating. Qi, Xiao, et al. (2017) reported that heat denaturation of whey proteins at temperatures above $70{ }^{\circ} \mathrm{C}$ could be prevented upon dry heat treatment with sugar beet pectin. Heat stable whey proteins solutions were also reported at $85{ }^{\circ} \mathrm{C}$ upon addition of $50 \mathrm{mM}$ salt (Mulcahy et al., 2016). The heat stability of the unadsorbed WPI has been reported to play an important role in the heat stability of WPI stabilized emulsions. As heat induced protein aggregation may cause the aggregation of unadsorbed WPI in the aqueous phase with the adsorbed proteins from two or more oil droplets, it follows that oil droplets may start aggregating, whereby the unadsorbed proteins may act as a glue in between the oil droplets (Fig. 5.a). This phenomenon was attributed solely to the presence of covalently bound polysaccharides, since dry heat treatment of whey proteins in the absence of polysaccharides did not exhibit the same result (Qi, Xiao, et al., 2017; Setiowati et al., 2016). Due to the strong electrosteric repulsion by binding with pectin, this phenomenon was largely prevented in the presence of WPILMP conjugates (Fig. 5.b). Moreover, it is believed that the conjugated proteins are more heat stable 
than the native ones, owing to their more rigid structure (Schong \& Famelart, 2017; Wang, He, Labuza, \& Ismail, 2013).

An increase in the denaturation temperature of whey proteins upon dry heat treatment with polysaccharides has been reported (Chen et al., 2015; Liu et al., 2014; Schong \& Famelart, 2017). Nevertheless, the authors reported that the denaturation temperature only increased by a couple of degrees, and hence can not explain the observed heat stability as such. On the other hand, conjugation of proteins with polysaccharides is known to reduce intermolecular interactions between proteins which play an important role in heat-induced protein aggregation (Schong \& Famelart, 2017). Therefore, the improved heat stability of whey proteins is most likely due to avoiding or slowing down the aggregation step, rather than by avoiding or slowing down the denaturation step.

It is worth to mention that whey protein-polysaccharide conjugates have been reported to be very suitable for encapsulation of active compounds (Devi, Sarmah, Khatun, \& Maji, 2017; Fan, Yi, Zhang, Wen, \& Zhao, 2017; Nooshkam \& Varidi, 2019). Besides improving the solubility and bioavailability of the encapsulated active compounds, whey protein-polysaccharide conjugates also protect them from unfavorable conditions, such as the presence of light or oxygen, or extreme $\mathrm{pH}$ conditions. Furthermore, since whey protein-polysaccharide conjugates possess an excellent heat stability, they also improve the heat stability of encapsulated active compounds, such as anthocyanins (Nooshkam \& Varidi, 2019; Qin et al., 2018).

\section{Conclusions and future works}

Native whey proteins are very heat labile. Heat denaturation and aggregation take place rapidly once they are heated above their denaturation temperature. In order to broaden their application, the heat stability of whey proteins needs to be improved. Dry heat treatment of whey proteins in the presence of polysaccharides has been proven to improve the heat stability of whey protein solutions, as well as of whey protein stabilized emulsions. Conjugated whey proteins are able to maintain their 
633 solubility after heating, which is crucial for their functionality. In addition, the resulting product has a

634 better heat stability and emulsifying activity than native whey proteins or dry heat treated whey

635 proteins (in the absence of polysaccharides). This phenomenon is attributed to electrosteric

636 stabilization by the conjugates, provided by the attached polysaccharides.

637 For future work, it will be interesting to determine the amount of conjugated whey proteins 638 adsorbed onto the surface of oil droplets. In addition, it might also be interesting to study the 639 performance of the conjugates in a system which contains casein, such as in skim milk. It is expected 640 that the presence of conjugates will prevent the denaturation and aggregation of the whey proteins

641 as well as their interaction with $\mathrm{k}$-casein during heat treatment and thus may prevent fouling of heat

642 exchangers. Lastly, it is also important to optimize the production of whey protein conjugates for 643 industrial application as the available methods mostly require a long (i.e. at least some hours to days) 644 dry heat treatment period. 
647

648

649

650

651

652

653

654

655

656

657

658

659

660

661

662

663

664

665

666

667

668

669

670

671

672

673

674

675

676

677

678

679

680

681

682

683

684

685

686

687

688

689

690

\section{References}

Akhtar, M., \& Dickinson, E. (2007). Whey protein-maltodextrin conjugates as emulsifying agents: an alternative to gum arabic. Food Hydrocolloids, 21(4), 607-616.

Ames, J. M. (1998). Applications of the Maillard reaction in the food industry. Food Chemistry, 62(4), 431-439. doi:http://dx.doi.org/10.1016/S0308-8146(98)00078-8

Anema, S. G., \& Li, Y. (2003). Association of denatured whey proteins with casein micelles in heated reconstituted skim milk and its effect on casein micelle size. Journal of Dairy Research, 70(01), 73-83. doi:doi:10.1017/S0022029902005903

Aoki, T., Hiidome, Y., Kitahata, K., Sugimoto, Y., Ibrahim, H. R., \& Kato, Y. (1999). Improvement of heat stability and emulsifying activity of ovalbumin by conjugation with glucuronic acid through the Maillard reaction. Food Research International, 32(2), 129-133. doi:http://dx.doi.org/10.1016/S0963-9969(99)00039-3

Bouvier, L., Moreau, A., Ronse, G., Six, T., Petit, J., \& Delaplace, G. (2014). A CFD model as a tool to simulate $\beta$-lactoglobulin heat-induced denaturation and aggregation in a plate heat exchanger. Journal of Food Engineering, 136, 56-63.

Brodkorb, A., Croguennec, T., Bouhallab, S., \& Kehoe, J. J. (2016). Heat-induced denaturation, aggregation and gelation of whey proteins. In Advanced dairy chemistry (pp. 155-178): Springer.

Bryant, C. M., \& Mc Clements, D. J. (1998). Molecular basis of protein functionality with special consideration of cold-set gels derived from heat-denatured whey. Trends in Food Science \& Technology, 9(4), 143-151.

Buggy, A. K., McManus, J. J., Brodkorb, A., Mc Carthy, N., \& Fenelon, M. A. (2017). Stabilising effect of $\alpha-$ lactalbumin on concentrated infant milk formula emulsions heat treated pre-or posthomogenisation. Dairy Science \& Technology, 96(6), 845-859.

Cayot, P., \& Lorient, D. (1997). Structure-function relationships of whey proteins. FOOD SCIENCE AND TECHNOLOGY-NEW YORK-MARCEL DEKKER-, 225-256.

Cheison, S. C., \& Kulozik, U. (2017). Impact of the environmental conditions and substrate pre-treatment on whey protein hydrolysis: A review. Critical reviews in food science and nutrition, 57(2), 418453.

Chen, H., Ji, A., Qiu, S., Liu, Y., Zhu, Q., \& Yin, L. (2018). Covalent conjugation of bovine serum album and sugar beet pectin through Maillard reaction/laccase catalysis to improve the emulsifying properties. Food hydrocolloids, 76, 173-183.

Chen, W., Lv, R., Wang, W., Ma, X., Muhammad, A. I., Guo, M., . . Liu, D. (2019). Time effect on structural and functional properties of whey protein isolate-gum acacia conjugates prepared via Maillard reaction. Journal of the Science of Food and Agriculture.

Chen, Y., Chen, X., Guo, T. L., \& Zhou, P. (2015). Improving the thermostability of $\beta$-lactoglobulin via glycation: The effect of sugar structures. Food research international, 69, 106-113.

Consoli, L., Dias, R. A., Rabelo, R. S., Furtado, G. F., Sussulini, A., Cunha, R. L., \& Hubinger, M. D. (2018). Sodium caseinate-corn starch hydrolysates conjugates obtained through the Maillard reaction as stabilizing agents in resveratrol-loaded emulsions. Food hydrocolloids, 84, 458-472.

Crowley, S. V., Dowling, A. P., Caldeo, V., Kelly, A. L., \& O'Mahony, J. A. (2016). Impact of $\alpha$-lactalbumin: $\beta$-lactoglobulin ratio on the heat stability of model infant milk formula protein systems. Food Chemistry, 194, 184-190.

Damodaran, S. (2005). Protein stabilization of emulsions and foams. Journal of Food Science, 70(3), R54R66. 
de Oliveira, F. C., Coimbra, J. S. d. R., de Oliveira, E. B., Zuñiga, A. D. G., \& Rojas, E. E. G. (2016). Food protein-polysaccharide conjugates obtained via the Maillard reaction: A review. Critical reviews in food science and nutrition, 56(7), 1108-1125.

Demetriades, K., Coupland, J. N., \& McClements, D. J. (1997). Physicochemical properties of whey protein-stabilized emulsions as affected by heating and ionic strength. Journal of Food Science, 62(3), 462-467. doi:10.1111/j.1365-2621.1997.tb04407.x

Devi, N., Sarmah, M., Khatun, B., \& Maji, T. K. (2017). Encapsulation of active ingredients in polysaccharide-protein complex coacervates. Advances in colloid and interface science, 239, 136-145.

deWit, J. N., \& Klarenbeek, G. (1984). Effects of Various Heat Treatments on Structure and Solubility of Whey Proteins. Journal of Dairy Science, 67(11), 2701-2710. doi:http://dx.doi.org/10.3168/jds.S0022-0302(84)81628-8

Dissanayake, M., \& Vasiljevic, T. (2009). Functional properties of whey proteins affected by heat treatment and hydrodynamic high-pressure shearing. Journal of Dairy Science, 92(4), 1387-1397. doi:http://dx.doi.org/10.3168/jds.2008-1791

Doost, A. S., Nasrabadi, M. N., Wu, J., A'yun, Q., \& Van der Meeren, P. (2019). Maillard conjugation as an approach to improve whey proteins functionality: a review of conventional and novel preparation techniques. Trends in Food Science \& Technology, 91, 1-11.

Drapala, K. P., Auty, M. A., Mulvihill, D. M., \& O'Mahony, J. A. (2016). Improving thermal stability of hydrolysed whey protein-based infant formula emulsions by protein-carbohydrate conjugation. Food research international, 88, 42-51.

Einhorn-Stoll, U., Ulbrich, M., Sever, S., \& Kunzek, H. (2005). Formation of milk protein-pectin conjugates with improved emulsifying properties by controlled dry heating. Food Hydrocolloids, 19(2), 329-340.

Euston, S. R., Finnigan, S. R., \& Hirst, R. L. (2000). Aggregation kinetics of heated whey protein-stabilized emulsions. Food Hydrocolloids, 14(2), 155-161. doi:http://dx.doi.org/10.1016/S0268005X(99)00061-2

Fan, Y., Yi, J., Zhang, Y., Wen, Z., \& Zhao, L. (2017). Physicochemical stability and in vitro bioaccessibility of $\beta$-carotene nanoemulsions stabilized with whey protein-dextran conjugates. Food hydrocolloids, 63, 256-264.

Ge Pan, G., \& Melton, L. D. (2007). Nonenzymatic browning of lactose and caseinate during dry heating at different relative humidities. Journal of agricultural and food chemistry, 55(24), 10036-10042.

Gentes, M.-C., St-Gelais, D., \& Turgeon, S. L. (2010). Stabilization of whey protein isolate- pectin complexes by heat. Journal of agricultural and food chemistry, 58(11), 7051-7058.

Gulzar, M., Bouhallab, S., Jeantet, R., Schuck, P., \& Croguennec, T. (2011). Influence of pH on the dry heat-induced denaturation/aggregation of whey proteins. Food Chemistry, 129(1), 110-116.

Haque, M. A., Aldred, P., Chen, J., Barrow, C. J., \& Adhikari, B. (2013). Comparative study of denaturation of whey protein isolate (WPI) in convective air drying and isothermal heat treatment processes. Food Chemistry, 141(2), 702-711.

Hoffmann, M. A., \& van Mil, P. J. (1999). Heat-induced aggregation of $\beta$-lactoglobulin as a function of $\mathrm{pH}$. Journal of Agricultural and Food Chemistry, 47(5), 1898-1905.

Jambrak, A. R., Mason, T. J., Lelas, V., Paniwnyk, L., \& Herceg, Z. (2014). Effect of ultrasound treatment on particle size and molecular weight of whey proteins. Journal of Food Engineering, 121, 15-23.

Jiménez-Castaño, L., López-Fandiño, R., Olano, A., \& Villamiel, M. (2005). Study on $\beta$-lactoglobulin glycosylation with dextran: effect on solubility and heat stability. Food Chemistry, 93(4), 689695.

Jiménez-Castaño, L., Villamiel, M., Martín-Álvarez, P. J., Olano, A., \& López-Fandiño, R. (2005). Effect of the dry-heating conditions on the glycosylation of $\beta$-lactoglobulin with dextran through the 
Maillard reaction. Food Hydrocolloids, 19(5), 831-837. doi:http://dx.doi.org/10.1016/j.foodhyd.2004.10.033

Jing, H., \& Nakamura, S. (2005). Production and use of Maillard products as oxidative stress modulators. Journal of medicinal food, 8(3), 291-298.

Kato, A. (2002). Industrial applications of Maillard-type protein-polysaccharide conjugates. Food Science and Technology Research, 8(3), 193-199.

Kehoe, J., \& Foegeding, E. (2014). The characteristics of heat-induced aggregates formed by mixtures of $\beta$-lactoglobulin and $\beta$-casein. Food Hydrocolloids, 39, 264-271.

Kessler, H.-G., \& Beyer, H.-J. (1991). Thermal denaturation of whey proteins and its effect in dairy technology. International Journal of Biological Macromolecules, 13(3), 165-173. doi:http://dx.doi.org/10.1016/0141-8130(91)90043-T

Kharlamova, A., Nicolai, T., \& Chassenieux, C. (2018). Calcium-induced gelation of whey protein aggregates: Kinetics, structure and rheological properties. Food hydrocolloids, 79, 145-157.

Kováčová, R., Synytsya, A., \& Štětina, J. (2009). Characterisation of whey proteins-pectin interaction in relation to emulsifying properties of whey proteins. Czech J. Food Sci, 27, S4-S8.

Lam, R. S., \& Nickerson, M. T. (2015). The effect of pH and temperature pre-treatments on the physicochemical and emulsifying properties of whey protein isolate. LWT-Food Science and Technology, 60(1), 427-434.

Law, A. J., \& Leaver, J. (2000). Effect of pH on the thermal denaturation of whey proteins in milk. Journal of Agricultural and Food Chemistry, 48(3), 672-679.

Liu, G., \& Zhong, Q. (2013). Thermal aggregation properties of whey protein glycated with various saccharides. Food Hydrocolloids, 32(1), 87-96. doi:http://dx.doi.org/10.1016/j.foodhyd.2012.12.008

Liu, G., \& Zhong, Q. (2015). High temperature-short time glycation to improve heat stability of whey protein and reduce color formation. Food Hydrocolloids, 44, 453-460.

Liu, Q., Kong, B., Han, J., Sun, C., \& Li, P. (2014). Structure and antioxidant activity of whey protein isolate conjugated with glucose via the Maillard reaction under dry-heating conditions. Food structure, 1(2), 145-154.

Lu, R., Li, W.-W., Katzir, A., Raichlin, Y., Yu, H.-Q., \& Mizaikoff, B. (2015). Probing the secondary structure of bovine serum albumin during heat-induced denaturation using mid-infrared fiberoptic sensors. Analyst, 140(3), 765-770.

Lucena, M. E., Alvarez, S., Menéndez, C., Riera, F. A., \& Alvarez, R. (2007). $\alpha$-Lactalbumin precipitation from commercial whey protein concentrates. Separation and purification technology, 52(3), 446453.

Martinez-Alvarenga, M., Martinez-Rodriguez, E., Garcia-Amezquita, L., Olivas, G., Zamudio-Flores, P., Acosta-Muniz, C., \& Sepulveda, D. (2014). Effect of Maillard reaction conditions on the degree of glycation and functional properties of whey protein isolate-Maltodextrin conjugates. Food Hydrocolloids, 38, 110-118.

Martins, G. A. D. S., Blanpain-Avet, P., Six, T., Lesur, A., Delaplace, G., \& Croguennec, T. (2016). Phosphate and calcium effects on the heat-denaturation of whey proteins and on the fouling mass deposited onto the surface of a heat exchanger surface. Paper presented at the 18 . World Congress of Food Science and Technology-IUFOST.

McGuffey, M. K., Otter, D. E., van Zanten, J. H., \& Foegeding, E. A. (2007). Solubility and aggregation of commercial $\alpha$-lactalbumin at neutral pH. International Dairy Journal, 17(10), 1168-1178.

Meng, J., Kang, T.-T., Wang, H.-F., Zhao, B.-B., \& Lu, R.-R. (2018). Physicochemical properties of caseindextran nanoparticles prepared by controlled dry and wet heating. International journal of biological macromolecules, 107, 2604-2610. 
Morgan, F., Léonil, J., Mollé, D., \& Bouhallab, S. (1999). Modification of Bovine $\beta$-Lactoglobulin by Glycation in a Powdered State or in an Aqueous Solution: Effect on Association Behavior and Protein Conformation. Journal of Agricultural and Food Chemistry, 47(1), 83-91. doi:10.1021/jf9804387

Mulcahy, E. M., Mulvihill, D. M., \& O'Mahony, J. A. (2016). Physicochemical properties of whey protein conjugated with starch hydrolysis products of different dextrose equivalent values. International dairy journal, 53, 20-28.

Murray, B. S., Durga, K., Yusoff, A., \& Stoyanov, S. D. (2011). Stabilization of foams and emulsions by mixtures of surface active food-grade particles and proteins. Food Hydrocolloids, 25(4), 627-638.

Nakamura, S., Suzuki, Y., Ishikawa, E., Yakushi, T., Jing, H., Miyamoto, T., \& Hashizume, K. (2008). Reduction of in vitro allergenicity of buckwheat Fag e 1 through the Maillard-type glycosylation with polysaccharides. Food Chemistry, 109(3), 538-545.

Nicolai, T., Britten, M., \& Schmitt, C. (2011). $\beta$-Lactoglobulin and WPI aggregates: formation, structure and applications. Food Hydrocolloids, 25(8), 1945-1962.

Nikolaidis, A., \& Moschakis, T. (2017). Studying the denaturation of bovine serum albumin by a novel approach of difference-UV analysis. Food Chemistry, 215, 235-244.

Nooshkam, M., \& Varidi, M. (2019). Maillard conjugate-based delivery systems for the encapsulation, protection, and controlled release of nutraceuticals and food bioactive ingredients: A review. Food hydrocolloids, 105389.

Oliver, C. M., Melton, L. D., \& Stanley, R. A. (2006). Creating proteins with novel functionality via the Maillard reaction: a review. Critical Reviews in Food Science and Nutrition, 46(4), 337-350.

Ozturk, B., \& McClements, D. J. (2016). Progress in natural emulsifiers for utilization in food emulsions. Current Opinion in Food Science, 7, 1-6.

Paul, L., McSweeney, F., \& Patrick, F. (2013). Advanced Dairy Chemistry: Volume 1A: Proteins: Basic Aspects (4 ed. Vol. 4): Springer.

Pelegrine, D. H. G., \& Gasparetto, C. A. (2005). Whey proteins solubility as function of temperature and pH. LWT - Food Science and Technology, 38(1), 77-80. doi:http://dx.doi.org/10.1016/j.Iwt.2004.03.013

Pirestani, S., Nasirpour, A., Keramat, J., Desobry, S., \& Jasniewski, J. (2017). Effect of glycosylation with gum Arabic by Maillard reaction in a liquid system on the emulsifying properties of canola protein isolate. Carbohydrate polymers, 157, 1620-1627.

Qi, P. X., Chau, H. K., Fishman, M. L., Wickham, E. D., \& Hotchkiss Jr, A. T. (2017). Investigation of the molecular interactions between $\beta$-lactoglobulin and low methoxyl pectin by multi-detection High Performance Size Exclusion Chromatography. Food Hydrocolloids, 63, 321-331.

Qi, P. X., Wickham, E. D., \& Garcia, R. A. (2014). Structural and thermal stability of $\beta$-lactoglobulin as a result of interacting with sugar beet pectin. Journal of Agricultural and Food Chemistry, 62(30), 7567-7576.

Qi, P. X., Xiao, Y., \& Wickham, E. D. (2017). Stabilization of whey protein isolate (WPI) through interactions with sugar beet pectin (SBP) induced by controlled dry-heating. Food Hydrocolloids, 67, 1-13.

Qin, X., Yuan, D., Wang, Q., Hu, Z., Wu, Y., Cai, J., . . . Liu, G. (2018). Maillard-Reacted Whey Protein Isolates Enhance Thermal Stability of Anthocyanins over a Wide pH Range. Journal of agricultural and food chemistry, 66(36), 9556-9564.

Ryan, K., Vardhanabhuti, B., Jaramillo, D., van Zanten, J., Coupland, J., \& Foegeding, E. (2012). Stability and mechanism of whey protein soluble aggregates thermally treated with salts. Food Hydrocolloids, 27(2), 411-420. 
Ryan, K. N., Zhong, Q., \& Foegeding, E. A. (2013). Use of Whey Protein Soluble Aggregates for Thermal Stability-A Hypothesis Paper. Journal of Food Science, 78(8), R1105-R1115. doi:10.1111/17503841.12207

Schmidt, U., Pietsch, V., Rentschler, C., Kurz, T., Endreß, H.-U., \& Schuchmann, H. (2016). Influence of the degree of esterification on the emulsifying performance of conjugates formed between whey protein isolate and citrus pectin. Food Hydrocolloids, 56, 1-8.

Schong, E., \& Famelart, M.-H. (2017). Dry heating of whey proteins. Food Research International, 100, 31-44.

Setiowati, A. D., Rwigamba, A., \& Van der Meeren, P. (2019). The influence of degree of methoxylation on the emulsifying and heat stabilizing activity of whey protein-pectin conjugates. Food hydrocolloids, 96, 54-64.

Setiowati, A. D., Saeedi, S., Wijaya, W., \& Van der Meeren, P. (2017). Improved heat stability of whey protein isolate stabilized emulsions via dry heat treatment of WPI and low methoxyl pectin: Effect of pectin concentration, pH, and ionic strength. Food hydrocolloids, 63, 716-726.

Setiowati, A. D., Vermeir, L., De Neve, L., Sedaghat Doost, A., Sinnaeve, D., \& Van der Meeren, P. (2018). Quantification of the electrostatic and covalent interaction between whey proteins and low methoxyl pectin using PFG-NMR diffusometry. Magnetic Resonance in Chemistry.

Setiowati, A. D., Vermeir, L., Martins, J., De Meulenaer, B., \& Van der Meeren, P. (2016). Improved heat stability of protein solutions and $\mathrm{O} / \mathrm{W}$ emulsions upon dry heat treatment of whey protein isolate in the presence of low-methoxyl pectin. Colloids and Surfaces A: Physicochemical and Engineering Aspects, 510, 93-103.

Shu, Y.-W., Sahara, S., Nakamura, S., \& Kato, A. (1996). Effects of the length of polysaccharide chains on the functional properties of the Maillard-type lysozyme-polysaccharide conjugate. Journal of Agricultural and Food Chemistry, 44(9), 2544-2548.

Sliwinski, E. L., Roubos, P. J., Zoet, F. D., van Boekel, M. A. J. S., \& Wouters, J. T. M. (2003). Effects of heat on physicochemical properties of whey protein-stabilised emulsions. Colloids and Surfaces $B$ : Biointerfaces, 31(1-4), 231-242. doi:http://dx.doi.org/10.1016/S0927-7765(03)00143-7

Spotti, M. J., Martinez, M. J., Pilosof, A. M. R., Candioti, M., Rubiolo, A. C., \& Carrara, C. R. (2014). Influence of Maillard conjugation on structural characteristics and rheological properties of whey protein/dextran systems. Food Hydrocolloids, 39, 223-230. doi:http://dx.doi.org/10.1016/j.foodhyd.2014.01.014

Stender, E. G., Koutina, G., Almdal, K., Hassenkam, T., Mackie, A., Ipsen, R., \& Svensson, B. (2018). Isoenergic modification of whey protein structure by denaturation and crosslinking using transglutaminase. Food \& function, 9(2), 797-805.

ter Haar, R., Schols, H. A., \& Gruppen, H. (2011). Effect of saccharide structure and size on the degree of substitution and product dispersity of $\alpha$-lactalbumin glycated via the Maillard reaction. Journal of agricultural and food chemistry, 59(17), 9378-9385.

Usui, M., Tamura, H., Nakamura, K., Ogawa, T., Muroshita, M., Azakami, H., . . Kato, A. (2004). Enhanced bactericidal action and masking of allergen structure of soy protein by attachment of chitosan through Maillard-type protein-polysaccharide conjugation. Molecular Nutrition \& Food Research, 48(1), 69-72.

Vardhanabhuti, B., \& Foegeding, E. A. (2008). Effects of dextran sulfate, $\mathrm{NaCl}$, and initial protein concentration on thermal stability of $\beta$-lactoglobulin and $\alpha$-lactalbumin at neutral $\mathrm{pH}$. Food hydrocolloids, 22(5), 752-762.

Vasbinder, A. J., van Mil, P. J., Bot, A., \& de Kruif, K. G. (2001). Acid-induced gelation of heat-treated milk studied by diffusing wave spectroscopy. Colloids and Surfaces B: Biointerfaces, 21(1), 245-250.

Verheul, M., Roefs, S. P., \& de Kruif, K. G. (1998). Kinetics of heat-induced aggregation of $\beta$-lactoglobulin. Journal of Agricultural and Food Chemistry, 46(3), 896-903. 
Wagoner, T. B., \& Foegeding, E. A. (2017). Whey protein-pectin soluble complexes for beverage applications. Food Hydrocolloids, 63, 130-138.

Walstra, P., Wouters, J., \& Geurts, T. (2006). Milk components. Dairy science and technology, 2, 17-108.

Wang, Q., He, L., Labuza, T. P., \& Ismail, B. (2013). Structural characterisation of partially glycosylated whey protein as influenced by $\mathrm{pH}$ and heat using surface-enhanced Raman spectroscopy. Food chemistry, 139(1-4), 313-319.

Wang, Q., \& Ismail, B. (2012). Effect of Maillard-induced glycosylation on the nutritional quality, solubility, thermal stability and molecular configuration of whey proteinv. International dairy journal, 25(2), 112-122.

Wang, W., Shen, M., Liu, S., Jiang, L., Song, Q., \& Xie, J. (2018). Gel properties and interactions of Mesona blumes polysaccharide-soy protein isolates mixed gel: The effect of salt addition. Carbohydrate polymers, 192, 193-201.

Wefers, D., Bindereif, B., Karbstein, H., \& van der Schaaf, U. (2018). Whey protein-pectin conjugates: Linking the improved emulsifying properties to molecular and physico-chemical characteristics. Food hydrocolloids, 85, 257-266.

Wijayanti, H. B., Bansal, N., \& Deeth, H. C. (2014). Stability of whey proteins during thermal processing: A review. Comprehensive Reviews in Food Science and Food Safety, 13(6), 1235-1251.

Wijayanti, H. B., Bansal, N., Sharma, R., \& Deeth, H. C. (2014). Effect of sulphydryl reagents on the heat stability of whey protein isolate. Food Chemistry, 163(0), 129-135. doi:http://dx.doi.org/10.1016/j.foodchem.2014.04.094

Wijayanti, H. B., Brodkorb, A., Hogan, S. A., \& Murphy, E. G. (2019). Thermal Denaturation, Aggregation, and Methods of Prevention. In Whey Proteins (pp. 185-247): Elsevier.

Xia, S., Li, Y., Zhao, Q., Li, J., Xia, Q., Zhang, X., \& Huang, Q. (2015). Probing Conformational Change of Bovine Serum Albumin-Dextran Conjugates under Controlled Dry Heating. Journal of Agricultural and Food Chemistry, 63(16), 4080-4086. doi:10.1021/jf506267r

Ye, A. (2008). Complexation between milk proteins and polysaccharides via electrostatic interaction: principles and applications-a review. International journal of food science \& technology, 43(3), 406-415.

Yohannes, G., Wiedmer, S. K., Elomaa, M., Jussila, M., Aseyev, V., \& Riekkola, M.-L. (2010). Thermal aggregation of bovine serum albumin studied by asymmetrical flow field-flow fractionation. Analytica chimica acta, 675(2), 191-198.

Zayas, J. F. (1997). Solubility of proteins. In Functionality of proteins in food (pp. 6-75): Springer.

Zha, F., Dong, S., Rao, J., \& Chen, B. (2019). Pea protein isolate-gum Arabic Maillard conjugates improves physical and oxidative stability of oil-in-water emulsions. Food chemistry, 285, 130-138.

Zhong, Q., Wang, W., Hu, Z., \& Ikeda, S. (2013). Sequential preheating and transglutaminase pretreatments improve stability of whey protein isolate at $\mathrm{pH} 7.0$ during thermal sterilization. Food hydrocolloids, 31(2), 306-316.

Zúñiga, R., Tolkach, A., Kulozik, U., \& Aguilera, J. (2010). Kinetics of Formation and Physicochemical Characterization of Thermally-Induced $\beta$-Lactoglobulin Aggregates. Journal of Food Science, 75(5). 


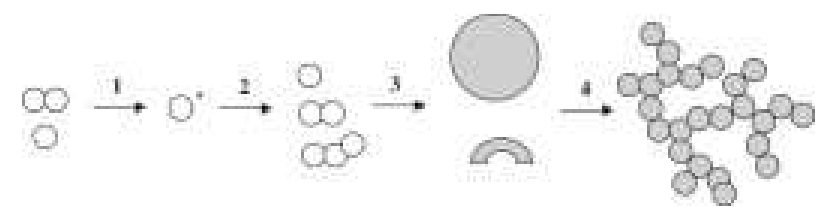

Figure 1. Schematic image of $\beta$-lactoglobulin aggregation (reprinted from Nicolai, Britten, and Schmitt (2011) with permission from Elsevier): 1. Whey proteins exist as monomers and dimers, whereby heating shifts the equilibrium towards monomers. 2. Formation of oligomers. 3. Formation of primary aggregates. 4. Formation of larger aggregates that can form a gel at certain concentrations.

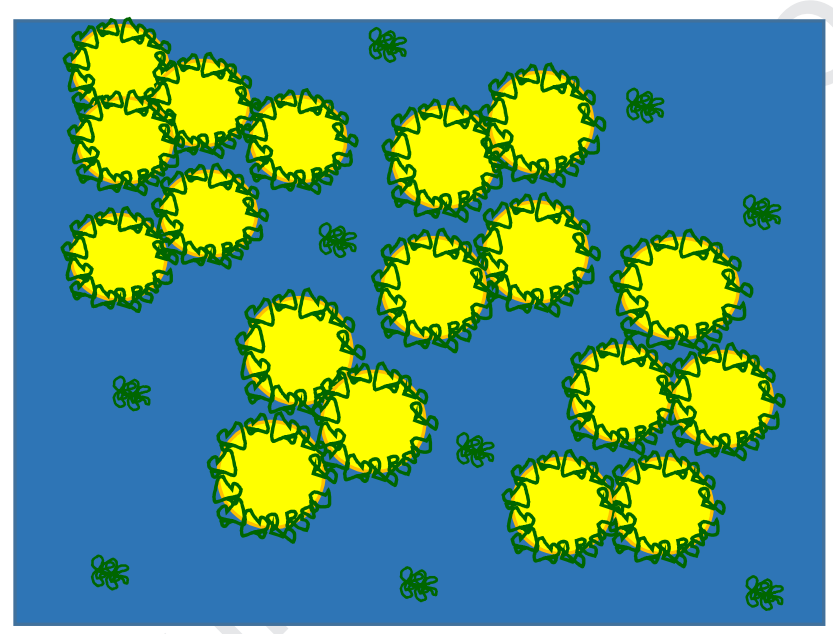

Figure 2. Schematic image of oil droplet aggregation due to the presence of denatured unadsorbed whey proteins which interact with adsorbed whey proteins. The unadsorbed whey proteins act as glue which binds the droplets together. 


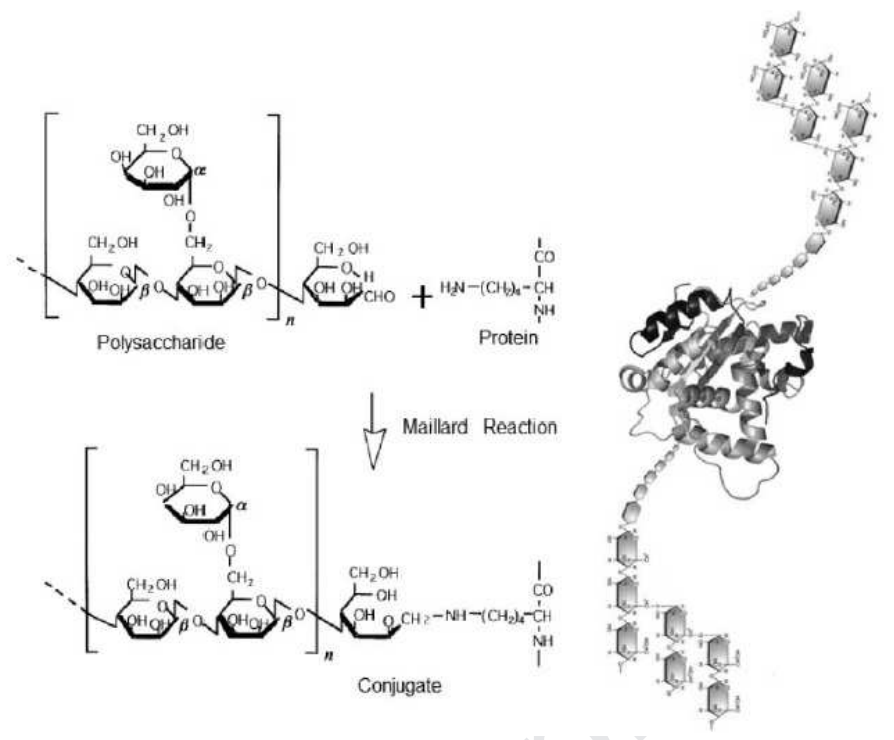

Figure 3. Schematic image of protein and polysaccharide conjugation via a Maillard type reaction (reprinted from de Oliveira, Coimbra, de Oliveira, Zuñiga, and Rojas (2016) with permission from Elsevier) 


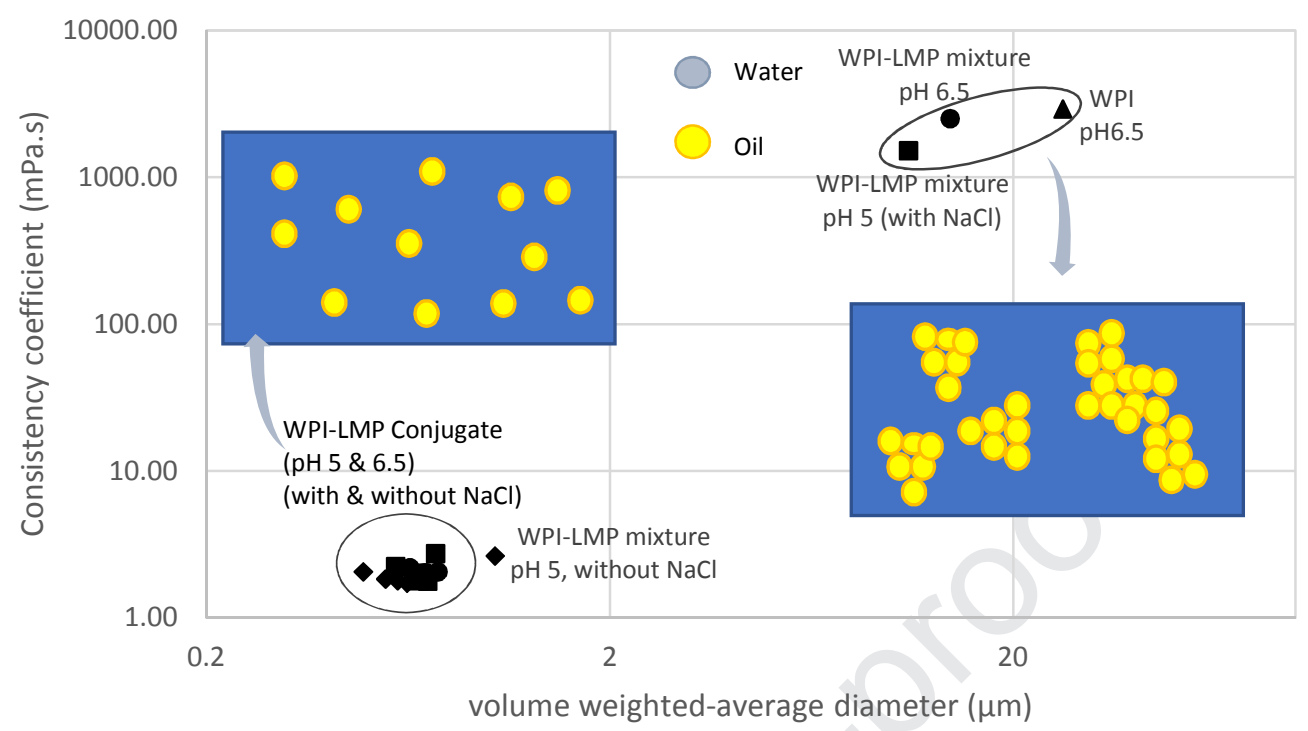

Figure 4. Consistency coefficient and volume-weighted average diameter of emulsions stabilized by WPIlow methoxy pectin (LMP) conjugates, WPI-LMP mixture, and native WPI at pH 5.0 and 6.5 in the absence and presence of $30 \mathrm{mM}$ salt, measured after heating at $80^{\circ} \mathrm{C}$ for $20 \mathrm{~min}$ (reprinted from Setiowati et al., (2017) with permission from Elsevier). 

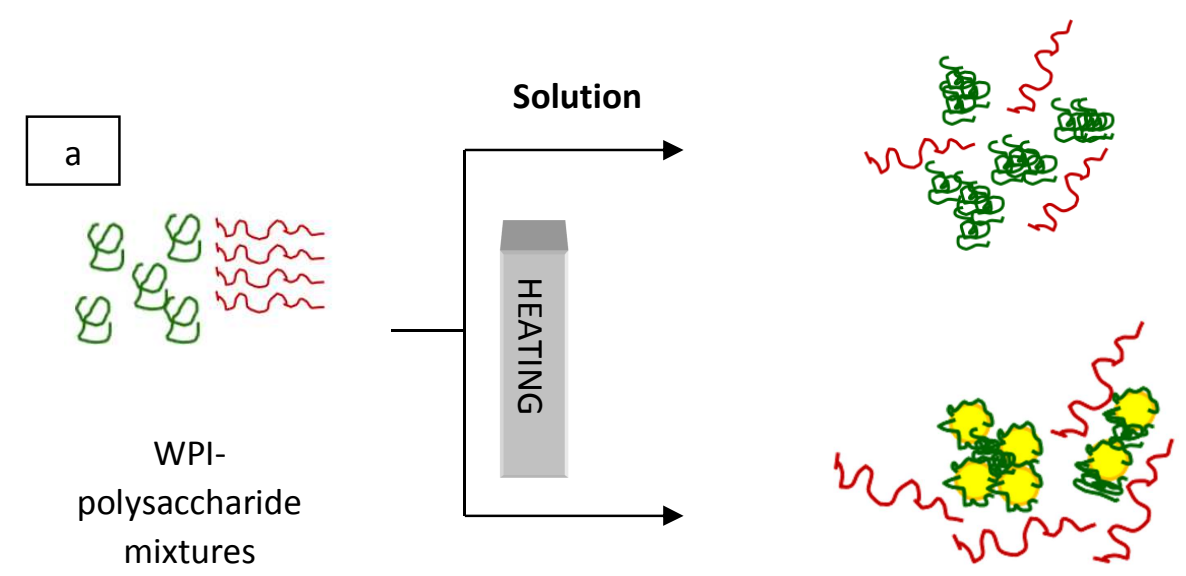

O/W Emulsion

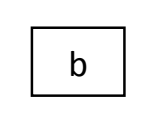

b

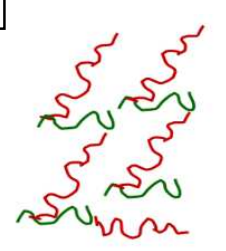

WPI-

Polysaccharide conjugates

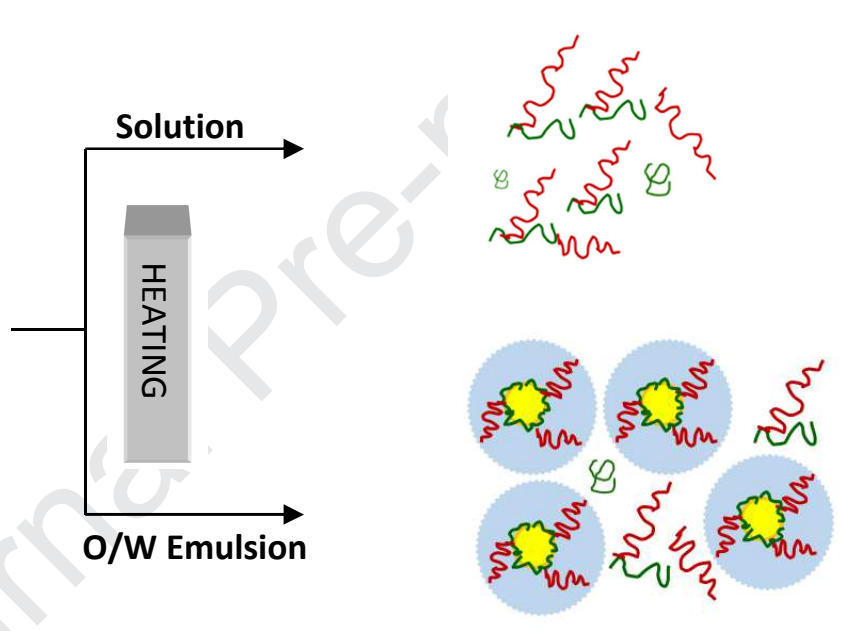

\section{N WPI \\ U $\Omega$ Polysaccharide}

Figure 5. Schematic illustration of the heat stabilizing activity of WPI-polysaccharide mixtures (a) and conjugates (b) in solution and in O/W emulsions. 


\section{Highlight}

- Whey proteins and whey protein stabilized emulsions are heat labile

- Heat stability is crucial for the broader industrial application of whey proteins

- Whey protein-polysaccharide conjugation largely increases the heat stability of whey proteins

- This is attributed to electrosteric stabilization provided by the attached polysaccharides. 